\title{
ROUX, Pierre-Emmanuel, La Croix, la baleine et le canon. La France face à la Corée au milieu du XIXe siècle, Paris, Editions du Cerf, 2012, 462 p.
}

Klaus Dittrich*

The present volume is an extended version of the author's master's thesis submitted to the Institut national de langues et civilisations orientales (INALCO) in Paris in 2007. It sets out to reinterpret the Franco-Korean connections from the 1840 s to the 1860 s. As the author explains in the introduction, the historiography of early Franco-Korean relations suffered from a too narrow focus on the expedition of 1866 as well as on the role of Korean Catholicism. Moreover, the early relations between France and Korea were largely asymmetrical. Whereas Korea played only a minor role for France and the history of the early contacts between both countries is only known to a small community of French specialists, the situation is completely different for Korea. The author underlines the relevance of early Franco-Korean contacts for Koreans with a personal anecdote in the preface, when he recounts the first encounter with his future father-in-law in Daejeon in 2002. On this occasion, the latter accused the author of belonging to a nation that invaded Korea in 1866 . The monograph is based on an impressive variety of hitherto unexploited documents from diverse countries, most importantly French diplomatic sources.

* Assistant Professor, Department of Literature and Cultural Studies, Education University of Hong Kong 
The first chapter focuses on French activities towards Korea during the 1840s. The unclear status of Korea, being at once independent and a tributary to the Qing dynasty, complicated the approach for all imperialist nations. The French regime of the July Monarchy aimed at strengthening its imperial prestige in competition with the British. In this context, the rear admiral Jean-Baptiste Cécille who had been sent to fight in the First Opium War, engaged in a mission to Ryūkyū, Nagasaki and Korea in 1846. As at the other destinations, Cécille, after having landed in Chungcheong province, left a letter to Korean authorities. Implicitly hoping for a preferential role of France in Korea, Cécille only demanded an explanation for the execution of three French missionaries in 1839 and announced to come back one year later in order to receive a response. It was Captain Edouard Lapierre who sailed to Korea in 1847 and was shipwrecked in Jeolla province, before being rescued by a British fleet. Lapierre's arrival caused panic in Korea and entailed the strengthening of anti-Catholic policies.

The second chapter deals with whale fishing as a pretext for opening up Korea. Whale products were one of the most important global commodities in the nineteenth century. The seas around East Asia, Japan in particular, have been whaling grounds for centuries. In 1851, the French whaler Le Narval shipwrecked on a small island in the waters of Jeolla province. Part of the crew was able to reach Shanghai. In turn, an expedition composed notably of the first French consul in Shanghai Charles de Montigny and his secretary Michel Kleczkowski reached Jeolla province and, after negotiations with local authorities, brought the remaining shipwrecked to China. Subsequently, Montigny became a veritable "herald of interventionism in Korea" and developed the idea of punishing the country for the supposedly bad treatment of the wrecked crews. Several rear admirals mapped the Korean coasts and prepared designs for opening the country, although their plans were not immediately carried out.

French main interests shifted to Vietnam when it became a formal colony in 1858. Similarly, the opening of Japan somehow marginalised Korea in French strategic thinking. Still, Montigny and Kleczkowski contin- 
ued to promote the idea of Korea as a secondary French base in East Asia. However, missionaries were the strongest advocates of an opening of Korea. This urge that favoured the use of power became even more pressing when the Daewongun had a number of missionaries and converts executed in early 1866 and three of the former were able to escape to China. Later that year, Pierre Gustave Roze was charged with a punitive expedition in which he unsuccessfully tried to impose religious freedom. This expedition also had economic motives, as is revealed by contemporary discourses on the supposed abundance of natural resources of Korea, be it gold, coal or ginseng.

The following chapter provides a more in-depth analysis of the 1866 expedition which in the eyes of contemporaries was an outcome of French frustrations accumulated over the previous decades. The expedition was preceded by an exploratory trip of Roze and three missionaries who sailed as the first Westerners up until Yanghwajin, almost reaching Seoul. Later on, seven ships with almost six hundred men blocked the Han river at Ganghwa for one month. The expedition, which had not been endorsed by the French Emperor Napoléon III, retreated when Roze realised that the objectives would not be reached and that they were militarily inferior to the arriving Korean reinforcements, but not before looting private and public property, including the local branch of the royal library. Roux informs us on the diverging readings of the event. The Koreans saw the outcome as their victory and were proud of having prevented a "new yuanmingyuan," referring to the Franco-British looting of the summer palace in Beijing in 1860. On the French side, some claimed the success of the mission, while other Westerners ridiculed France for its inability to open Korea.

Chapter 5 discusses the French (and British) perception of Russian expansionism. Roux puts forth the argument that the French attempts to open Korea have to be seen in the context of competition of imperial powers. A possible French colonisation of Korea was not an end in itself but would have primarily served at stopping Russia from strengthening its influence in East Asia. This kind of thinking matured in the context of the 
Crimean War (1853-1856) which opposed France and Britain to the Tsarist Empire. As Roux points out, the 1866 expedition has to be seen from this perspective, too. This constellation was remarkably different from Franco-Russian imperial cooperation in Korea around 1900.

The final chapter develops an additional perspective on France's interventionism. Roux argues that gun boat diplomacy in Korea aimed at being an object lesson in Western power for Chinese government and civilians alike who continued to nurture a negative opinion on the Western presence in general and Catholic missionaries in particular. Following this line of thinking, a strong hand in Korea would discipline the Chinese and in this way protect Westerners in China.

All in all, Roux underlines that France's engagement with Korea was a combination of religious, economic and strategic considerations. The protection of Catholic missionaries was often only used as a pretext for other purposes. Generally speaking, French actors were rarely interested in Korea as such. Instead, they used their policy towards the peninsula for other projects: competition with Russia, Chinese internal affairs, the assertion of imperial standing. The conclusion ends with recent debates on the restitution of books looted from Ganghwa-do. In this way it becomes clear that the actions of 1866 had in the long run a rather negative impact on the diplomatic relations between both countries.

What is striking is the transnational dimension of the book, although the author does not even once use this term in his analysis. Roux presents the context of and interactions between China, Japan, Russia and Vietnam, and also highlights the competition and cooperation with Britain as well as other European powers present in Asia. It becomes clear that France's engagement with Korea was tightly related to events in Vietnam and China. Many contemporary French decision-makers compared Korea to Vietnam. Therefore, the story Roux tells is in its essence much more than a bilateral Franco-Korean history. Similar to many publications that treat bilateral relations of Western powers and Korea, the book would have profited from more engagement with other fields of historical inquiry. Besides reference to genuinely transnational secondary literature, the 
monograph would have gained from embedding it in recent research on French imperialism.

Furthermore, Roux' account is to a large extent a history of diplomatic and military men. The biographical notes of the main actors gathered at the end of the book will be useful for researchers. The focus on the actors shows that interests of the French government, Catholic missionaries and military personnel stationed in Asia often conflicted. Missionaries liked to pressure French officials into punitive actions against anti-Catholic Asian governments, whereas the Parisian Ministry of Foreign Affairs was usually reluctant in engaging in military adventures. There was no homogenous French approach to Korea. One wonders if a stronger focus on other groups of actors beyond the admirals, diplomats and missionaries would have still broadened and diversified the narrative.

Finally, the book is particularly interesting where it discusses the micro-history of diplomatic dealings with Korea. Imprecise maps made it difficult and dangerous to sail in Korean waters. The exact location of Seoul was for a long time unknown. When Western ships landed in Korea, communication was extremely difficult and sometimes impossible. Chinese characters often served as a lingua franca. The book has its strength where Roux complements French with Korean sources. In this way, Roux shows the Korean decision making processes following the landing of French ships. These were processes of which the French were not aware. Lack of knowledge on government structures could lead to many misunderstandings.

All in all, this is a fascinating account on early contacts between France and Korea. Roux is now maître de conférences at the Université Paris Diderot-Paris 7. One will look forward to reading his doctoral dissertation on Catholicism in China and Korea during the eighteenth and nineteenth centuries. 
